\title{
STEM DENSITY AND GROWTH OF ATTALEA MARIPA AND ASTROCARYUM ACULEATUM: IMPLICATION FOR ARBORESCENT PALMS DISTRIBUTION ACROSS AMAZONIAN FORESTS
}

\author{
Rodolfo Salm ${ }^{1}$ \\ Date Received:06/27/2003 \\ Revised: 09/25/2003 \\ Accepted: 01/05/2004 \\ ${ }^{1}$ School of Environmental Sciences \\ University of East Anglia \\ Norwich NR4 7TJ, United Kingdom \\ e-mail: rodolfosalm@alternex.com.br
}

Biota Neotropica v4(n1) - http://www.biotaneotropica.org.br/v4n1/pt/abstract?article+BN00104012004

Send proofs to author's present address:Universidade Federal de São Carlos, Programa de Pós-graduação em Ecologia e Recursos Naturais, Rododovia Washington Luís, km 235, Monjolinho. CEP:13565-905, São Carlos, SP Brazil

\begin{abstract}
This study examines aspects of the stem density and growth of two large arborescent palms Attalea maripa and Astrocaryum aculeatum and discusses their implication for the palm trees distribution in Amazonia. Stem density and growth were investigated through both laboratory measurements and field estimates of growth rates. The densities of stem samples collected within one individual of each studied species were very distinct. The samples of $A$. maripa stem were more homogeneous in density than those of A. aculeatum, both from the internal to the external, and from the lower to the upper parts of the stem. Field estimates of stem growth rates revealed that $A$. maripa growth is also more constant through development in height. Short $A$. aculeatum palms had faster growth rates than A. maripa, as they get taller, stem growth rates are reduced and approach A. maripa rates. The implications for arborescent palms distribution across Amazonian forests are discussed.
\end{abstract}

Key words: Amazonia, Astrocaryum aculeatum, Attalea maripa, Distribution, Palms, Stem density

\section{Resumo}

Este estudo examina aspectos da densidade do caule e crescimento de duas palmeiras arborescentes de grande porte Attalea maripa e Astrocaryum aculeatum e discute suas implicações para a distribuição de palmeiras arborescentes na Amazônia. Densidade dos caules e crescimento foram investigados através de uma combinação de medidas de laboratório e estimativas de campo de taxas de crescimento. As densidades de amostras do caule coletadas de um indivíduo de cada espécie foram muito distintas. As amostras do caulde de $A$. maripa foram mais homogêneas em densidade que aquelas de A. aculeatum, tanto das partes internas para externas, como inferiores para superiores dos caules. Estimativas de campo de crescimento do caule revelaram que o crescimento de A. maripa também é mais constante ao longo do desenvolvimento. Palmeiras A. aculeatum baixas tiveram crescimento mais rápido que A. maripa, palmeiras mais altas têm seu crescimento reduzido a níveis semelhantes ao de A. maripa. São discutidas as implicações para a distribuição de palmeiras na Amazônia.

Palavras-chave: Astrocaryum aculeatum, Attalea maripa, Densidade do caule, Distribuição, Palmeiras. 


\section{Introduction}

The occurrence of disturbance seems to be a limiting factor for the distribution of different life-forms of palms in tropical forests. Early naturalists noticed the general rarity of palm trees in dense, well-drained forest areas (Spruce 1871). In the Amazonian terra firme forests, the distribution of the arborescent palms is partly determined by heterogeneity in topography (Kahn \& Granville 1992, Svenning 1999) and canopy cover (Richards \& Williamson 1975, Svenning 1999, 2000). Palm trees are abundant in open forests, which tends to be less developed architecturally, with large and complex canopy gaps, permitting greater level of light penetration through the understorey (Kahn \& Castro 1985, Kahn 1987).

The importance of forest disturbance regime as a determinant of palm tree occurrence and distribution has been attributed to their high light requirements for early establishment (Kahn \& Castro 1985, Kahn 1987, Kahn \& Granville 1992, but see Svenning 1999). The ecological light compensation point of establishing and adult palms increases throughout palm development. This occurs because the relative amount of support tissues in the leaves grow with leaf size and the fraction of biomass allocated to leaves declines with stem height (Givnish 1979, 1988, Tomlinson 1990).

In large gaps, trees along gap edges are relatively inefficient in promoting canopy closure. Thus, forest regeneration is mainly a result of new tree development, which takes considerably longer than regeneration from bordering trees on small gaps. Therefore, in large canopy gaps, light demanding palm trees often have sufficient time to complete their establishing growth under such favourable light conditions (Kahn 1986, Kahn \& Granville 1992, de Granville 1992).

Palms lack a lateral vascular cambium and, in the absence of any secondary thickening meristem, thickness growth is entirely primary, and confined to the apical meristem. Thus, stem girth growth largely precedes the completion of extension growth. The consequence is that palm trees, in contrast to dicotyledonous trees, are more limited in their capacity to increase stem diameter by cell division (Tomlinson 1961, 1979, Tomlinson \& Zimmermann 1967).

Palm trees represent exceptionally dynamic structures in which major age-dependent changes occur in mechanical properties (Rich 1986). The mechanical structure of arborescent palms is therefore fundamentally different from that of dicotyledon trees. The palm stem is more heterogeneous and undergoes more marked internal changes. Within the palm tree stem, density tends to be higher towards both the stem periphery and its base (Richolson \& Swarup 1977, Sudo 1980, Killmann 1983). Stiffness increase within palm stems prevents a steep growth in the risk of mechanical failure (Tomlinson \& Zimmerman 1967, Tomlinson 1979, 1990). Den- sity of peripheral stem tissues at the base of mature palm trees is higher than that of most dicotyledon, while the density of the central core, toward the crown, tends to be lower than most woods. Thus, a single mature arborescent palm can encompass the full range of published values of wood density (Williamson 1984).

The imbalance between the development of the palm stem and their mechanical support requirements poses anatomical constraints for arborescent palms in tropical forests. Inter-specific variation in stem development among Neotropical palm tree species might affect species growth rates and their performance in forests of contrasting architecture (Rich 1987a, Tomlinson 1990).

The aim of this study is to examine aspects of the stem structure and development of two large arborescent palms in a seasonally dry Amazonian forest and the ecological correlates of stem development. The establishment growth of Attalea maripa and Astrocaryum aculeatum was related to the morphometrics of both palm species. Stem structure and development were investigated through laboratory measurements of density and field estimates of stem growth rates.

\section{Material and Methods}

Attalea maripa is a tall (10 to $15 \mathrm{~m}$ height), massive, solitary and monoic palm (Uhl \& Dransfield 1987). The species is found throughout the Amazonian region, being widespread towards the open forests of its periphery, but it is not found outside Amazonia (Uhl \& Dransfield 1987, Kahn \& Granville 1992). A. maripa can become common in highly seasonal forests and is frequently dominant in secondary forests across their distribution range (Henderson et al. 1995). The fruits of this palm represent a major food source for the vertebrate community in several parts of the Amazon (Bodmer 1991, Kahn \& Granville 1992, Fragoso 1994, 1997, 1998, 1999).

Astrocaryum aculeatum is also a tall (10 to $25 \mathrm{~m}$ height), massive, solitary and monoic palm (Uhl \& Dransfield 1987). The upper part of its stem is armed with long black spines arranged in regularly spaced rings. As the tree grows, the oldest spines drop off, and lower trunk parts generally have no spines. This species is restricted to the Amazon region although less widespread than A. maripa towards its periphery (Uhl \& Dransfield 1987, Kahn \& Granville 1992). This species can become common in the dense forest of central Amazonia where it occasionally dominates secondary forests (Kahn \& Granville 1992, Henderson et al. 1995).

This study was conducted at the Pinkaití forest of southeastern Amazonia (7 46'18"S; 51 1 57'42"W). Geologically, the study area lies on the pre-Cambrian crystalline shield of Brazil. Annual rainfall is approximately $2000 \mathrm{~mm}$.yr ${ }^{1}$ and there is a severe dry season from June to September, when total rainfall is close to nil. The Pinkaití site is floristi- 
cally much heterogeneous and its tree species diversity is low, compared to more aseasonal sites elsewhere in the region (Baider 2000, Salm 2002), which is typical of transitional forests of southern and eastern Amazonia (Pires \& Prance 1985, Campbell et al., 1986). It is chiefly dominated by open forests, typically characterised by a high abundance of lianas (Ballé and Campbell 1990), and dense forests, that predominates in residual plateaus and other upland areas (Radam 1974). At the study site, there is a generally high density of $A$. maripa $\left(6.7 \pm 11.2\right.$ S.D palms. ha $\left.{ }^{-1}\right)$ that is consistently more abundant than $A$. aculeatum $(1.6 \pm 3.8$ S.D palms. ha-1). The palm family, in addition to $A$. maripa and $A$. aculeatum, also includes the arborescent Euterpe precatoria and Socratea exorrhiza, which are found in lower densities (Salm 2002).

The morphometrics and the field estimates A. maripa and $A$. aculeatum stem growth rates were measured within a 16ha grid system set in a forest path where the forest had apparently been cleared for subsistence crops in the first half of last century (U. Kayapo, pers. comm.). The Rutaceae is the family with highest number of stems, chiefly represented by Metrodorea flavida, the most numerous tree species in this assemblage. The palm A. maripa was the tree species with the highest basal and the second highest numerical abundance. On the other hand, A. aculeatum was the $16^{\text {th }}$ most common species in terms of basal area and the $10^{\text {th }}$ in individuals number (Salm 2002).

\subsection{Stem structure and development}

The diameter of 111 A. maripa and 50 A. aculeatum trees with above-ground stem were measured within the 16 ha grid system. It was possible to determinate the reproductive development stage of a total of $246 \mathrm{~A}$. maripa and $41 \mathrm{~A}$. aculeatum palms by an inspection for evidence or absence of past reproductive activity, as indicated by the accumulation of old seed and flower remnants underneath the crown. Heights were estimated using a $8 \mathrm{~m}$ long pole for reference from the ground to the lowest leaf-bearing node.

One individual palm of each species was destructively sampled outside the grid-system near the Pinkaiti research station. The A. maripa palm sampled was $8 \mathrm{~m}$ tall and had a cross-section of the stem collected at 0,4 and $8 \mathrm{~m}$ above ground. The $A$. aculeatum sampled was $16 \mathrm{~m}$ tall and had samples collected at $0,4,8,12$ and $16 \mathrm{~m}$. Both palms were reproductive adults and occurred under similar environmental condition, with the crown fully exposed, above the canopy.

Three whole cross-sections of A. maripa and five of A. aculeatum corresponding to the different height along the stem were taken to the Plant Anatomy Laboratory of the University of São Paulo (USP) for density measurements. Stem sections were photographed and milled into cubes. From each stem sections, 9 cubic samples were extracted, three of each from its central, intermediate and external parts. Because of practicality, stem tissue density was measured as oven-dry weight per dry volume. After samples were dried at $60^{\circ} \mathrm{C}$ for 30 days. All samples were weighed in a precision scale and their volume subsequently measured as the water volume displaced by the immersion of the sample in a graduated beaker.

\subsection{Growth rate estimates}

The palm family is characterised by a continuous production of leaves, and many palm species produce permanent leaf scars on the stem. Rates of leaf formation, internode distances, or rate of leaf expansion have been used to estimate the growth rate and age of palms (Corner 1964, Sarukhan 1978, Savage and Ashton 1983, Piñero et al. 1984, Uhl \& Dransfield 1987). It is feasible to estimate the growth rate of palms with data collected at relatively short periods of time. However, extrapolations from mean values should be considered with caution (Tomlinson 1979, 1990, Rich 1987a). Furthermore, age estimates of stemmed individuals still require information about the seedling and juvenile lifespan which in most large arborescent palms is difficult since their stems are protected and remain invisible below ground (Corner 1964, Tomlinson 1990).

For this study, leaf scar production rates were estimated by counting the number of leaves that fell from 81 adult $A$. maripa and 36 A. aculeatum during a 1-year period. At the beginning of this investigation period all fallen leaves were removed from the surroundings of the focal palms selected for observation. Fallen leaves, hanging from branches of surrounding trees were also removed. Fallen leaves were defined as those that had no base contact with the palm stems. All focal palms were subsequently monitored during three occasions (at four months interval) when all the new fallen leaves were counted and removed. The time interval between consecutive leaf counts was short enough to ensure that fallen leaves did not decay on the forest floor.

Leaf scars were counted with the assistance of a pair of binoculars along 67 adult $A$. maripa and 38 A. aculeatum stems. Leaf abscission marks are conspicuous in both $A$. maripa and A. aculeatum. Counts were classed within $1 \mathrm{~m}$ intervals, with reference to a $8 \mathrm{~m}$ long banded pole placed next to the focal palm stem. Leaf scars above $8 \mathrm{~m}$ along the palm stems were counted together as a single class. Counts were classed within $1 \mathrm{~m}$ intervals, with reference to a $8 \mathrm{~m}$ long banded pole placed next to the focal palm stem. Leaf scars above $8 \mathrm{~m}$ along the palm stems were counted together as a single class. Dividing the number of leaf marks along the stem by annual leaf production rates allowed stem growth rates to be estimated.

The palms considered for the leaf scar production rates estimation were not necessarily the same of those where leaf scars were counted, because of the distinct re- 
quirements of good visual access to the stem, and to the crown, in a forest where heavy liana loads cover most of the trees.

\section{Results}

\subsection{Stem structure and development}

The diameter of the A. maripa palms $(26.7 \mathrm{~cm} \pm 4.1$ $\mathrm{SD})$ was significantly higher than those of $A$. aculeatum $(23.7 \mathrm{~cm} \pm 3.9 \mathrm{SD})$ (Independent sample $\mathrm{T} \mathrm{p}=0.001)$. The height of the sampled $A$. maripa population $(8.2 \mathrm{~m} \pm 3.9 \mathrm{SD})$ is significantly lower of that of A. aculeatum $(14.4 \mathrm{~m} \pm 4.3$ SD) (Mann-Whitney U p=0.001) (Fig. 1). There was a positive relationship between palm girth and height in $A$. maripa ( $\left.\mathrm{r}_{\mathrm{s}}=0.304 ; \mathrm{p}=0.001\right)$, while no such correlation is found with A. aculeatum $\left(\mathrm{r}_{\mathrm{s}}=0.024 ; \mathrm{p}=0.871\right)$. The low number of $A$. aculeatum trees, especially those of low height, hinders interpretation of the pattern found.

Among the palms, which the reproductive development stage could be accessed, nonreproductive A. maripa were significantly shorter $(2.4 \pm 2.2 \mathrm{~m} ; \mathrm{n}=33)$ than reproductive ones $(10.0 \pm 2.6 \mathrm{~m} ; \mathrm{n}=213)$ (Mann-Whitney $\mathrm{U}, \mathrm{p}=0.001)$. Non-productive $A$. aculeatum were also significantly shorter $(4.4 \pm 2.0 \mathrm{~m} ; \mathrm{n}=5)$ than reproductive ones $(13.1 \pm 4.3 \mathrm{~m} ; \mathrm{n}=36)$ (Mann-Whitney $\mathrm{U}, \mathrm{p}=0.001$ ). All the non-productive virgin palms were less than $9 \mathrm{~m}$ tall, while most of the reproductive ones where taller than such limit (Fig. 2).

Variations were found in the aspect and density of $A$. maripa and $A$. aculeatum stem sections, both from the border to the centre and from the lower to upper parts of the palm. Fibrous bundles were more abundantly found towards the stem periphery. Both A. maripa and A. aculeatum showed higher density of fibrous material at lower and external parts of their stems, a pattern which is more conspicuous for $A$. maripa than A. aculeatum. Density of $A$. maripa and $A$. aculeatum is higher towards both the lower and the external parts of the stem, a pattern that is substantially less clearly defined for A. maripa than for A. aculeatum (Fig. 3).

\subsection{Stem growth}

In the year period from April 1998 to April 1999, the mean number of new leaves $( \pm \mathrm{SD})$ produced by $A$. maripa and $A$. aculeatum was $3.6 \pm 1.5(\mathrm{n}=81)$ and $4.0 \pm 1.5(\mathrm{n}=37)$. Because there was no significant correlation between palm height and the number of leaves produced for either species (A. maripa $-\mathrm{r}=0.183 \mathrm{p}=0.053 ;$ A. aculeatum $-\mathrm{r}=0.195 \mathrm{p}=$ $0.128)$, the average values were used to estimate palm growth rate. As said in methods, dividing the number of leaf marks along the stem by annual leaf production rates allowed stem growth rates to be estimated. Stem growth rate is higher in A. aculeatum. Growth rates of both species decrease with height (Fig. 4). The rate of decrease however is initially higher for A. maripa and consequently the species takes significantly longer than $A$. aculeatum to reach $8 \mathrm{~m}$ height aboveground (Fig. 5, Chi-square value, p=0.006).

\section{Discussion}

Neotropical palms range widely from shade tolerant to needing high levels of light (Svenning 2001). For example, cloning, in tropical forest palms, is a strategy that allow specimens to grow and persist under highly shaded conditions by the physiological integration of ramets, allowing the distribution of resources, from sites of acquisition, to sites where the resource is scarce (Souza et al. 2003). Arborescent palms, in particular, become increasingly lightdemanding with increasing size (de Granville 1992) and generally depend on large gaps for recruitment to the adult stage (Kahn 1986). J.-C. Svenning (1999) predicted that, if microhabitat niche differentiation is important for maintaining the species richness of the community, palms of similar growth form will show antagonistic microhabitat relationships. However, he could not find antagonistic patterns of microhabitat preferences among arborescent canopy palms.

The niche diversification hypothesis (Connell 1978) states that species coexist by occupying different niches. Because the arborescent palms Attalea maripa and Astrocaryum aculeatum are close relatives (both belong to the tribe cocoeae), are superficially similar, have comparable total leaf area, and comparable energy budget for their stem development, these species are likely to be direct competitors. However, the species coexist in vast areas of the core of the Amazonian region, where their distribution is superimposed (Henderson et al. 1995). The present work shows marked differences on the stem density and growth of these palms. Such differences, on palms of similar growth, through their probable implication for the species distribution, could be a large contribution to the "microhabitat niche differentiation" necessary for their stable co-existence.

The stems of $A$. maripa are significantly thicker than those of A. aculeatum and their DBH is weakly positively correlated with palm height. Such a relationship has been understood as evidence of capacity to increase in stem diameter by means of sustained cell expansion or primary cell division within the ground tissue (Corner 1964, Rich 1987a, 1987b, Waterhouse and Quinn 1978). It would be inappropriate to attach much meaning to the absence of a correlation between $A$. aculeatum stem height and girth, in light of the small sample size of short $A$. aculeatum trees in the sampling areas.

The range of density values of $A$. maripa and $A$. aculeatum stems covers a large part of the total observed variation in wood density values of Amazonian forest dicotyledonous trees, as predicted by Williamson (1984). Stem densities decreased in A. maripa and A. aculeatum, both from the stem periphery to the core and from the bottom to 


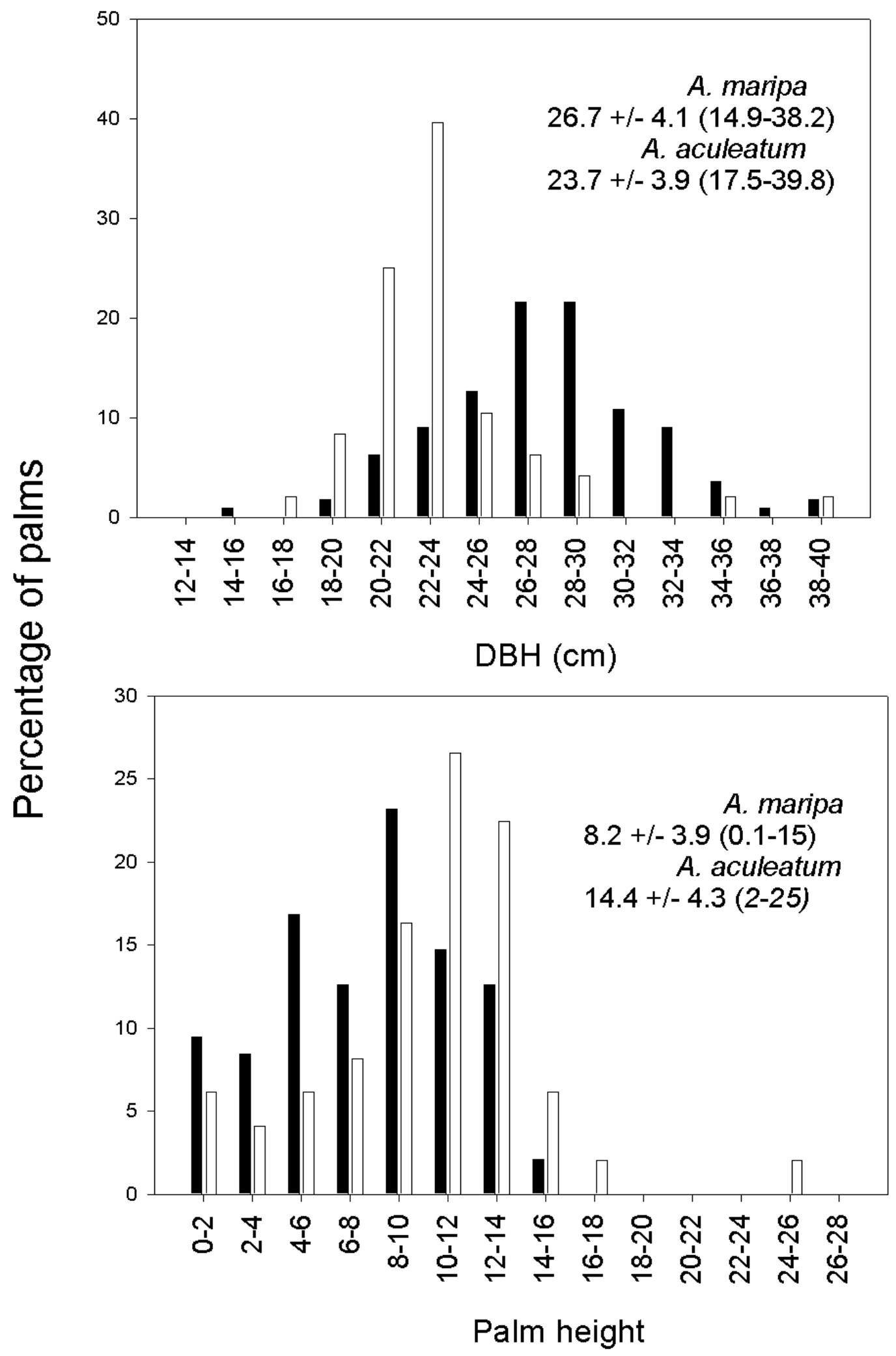

FIGURE 1. Frequency diagrams of the trunk DBH and height for 111 individual A. maripa (black) and 55 A. aculeatum (white) in the Pinkaití research station -Mean +/- SD (min-max). 


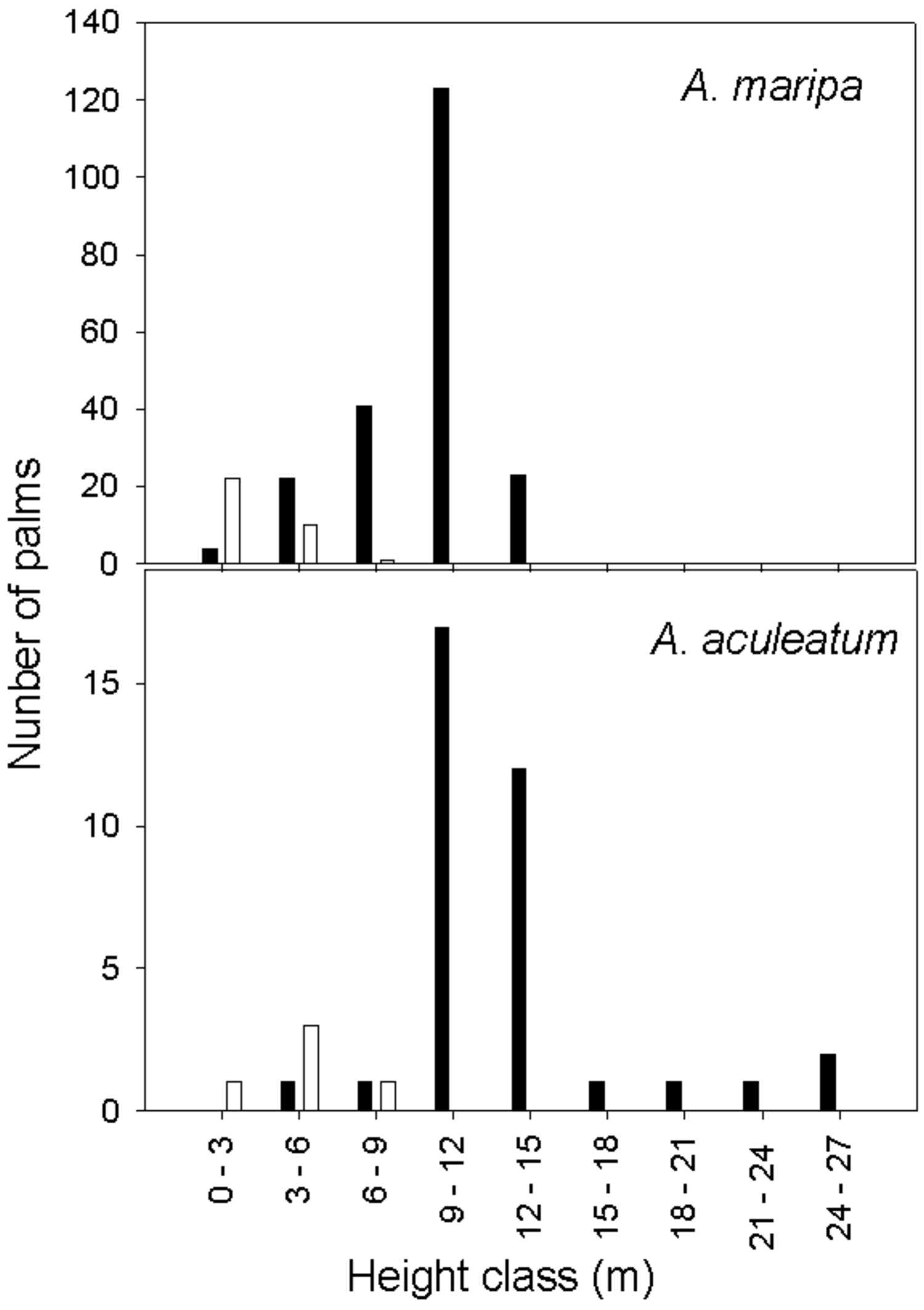

FIGURE 2. Frequency diagrams of reproductive stage and height of 246 individual A. maripa and 41 A. aculeatum. White and black bars represent, non-reproductive and reproductive palms, respectively. 


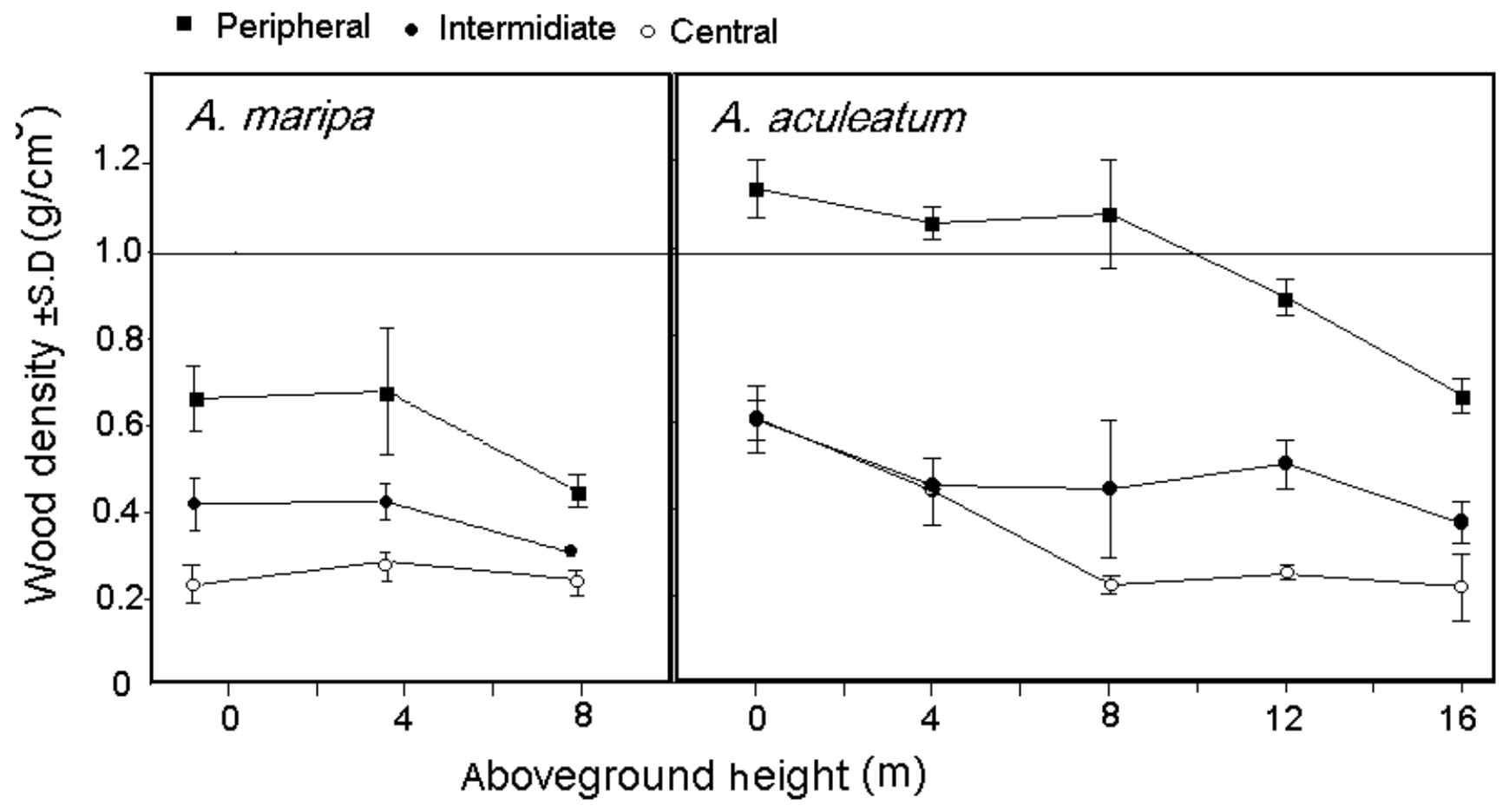

FIGURE 3. Distribution of stem tissue density in longitudinal section within a 8-m-tall A. maripa and a 16-m-tall A. aculeatum. Dry density is plotted as a function of height above ground for peripheral, intermediate and central stem tissue. Dry density is expressed as oven-dry weight over volume. $N=9$ for each position and height.

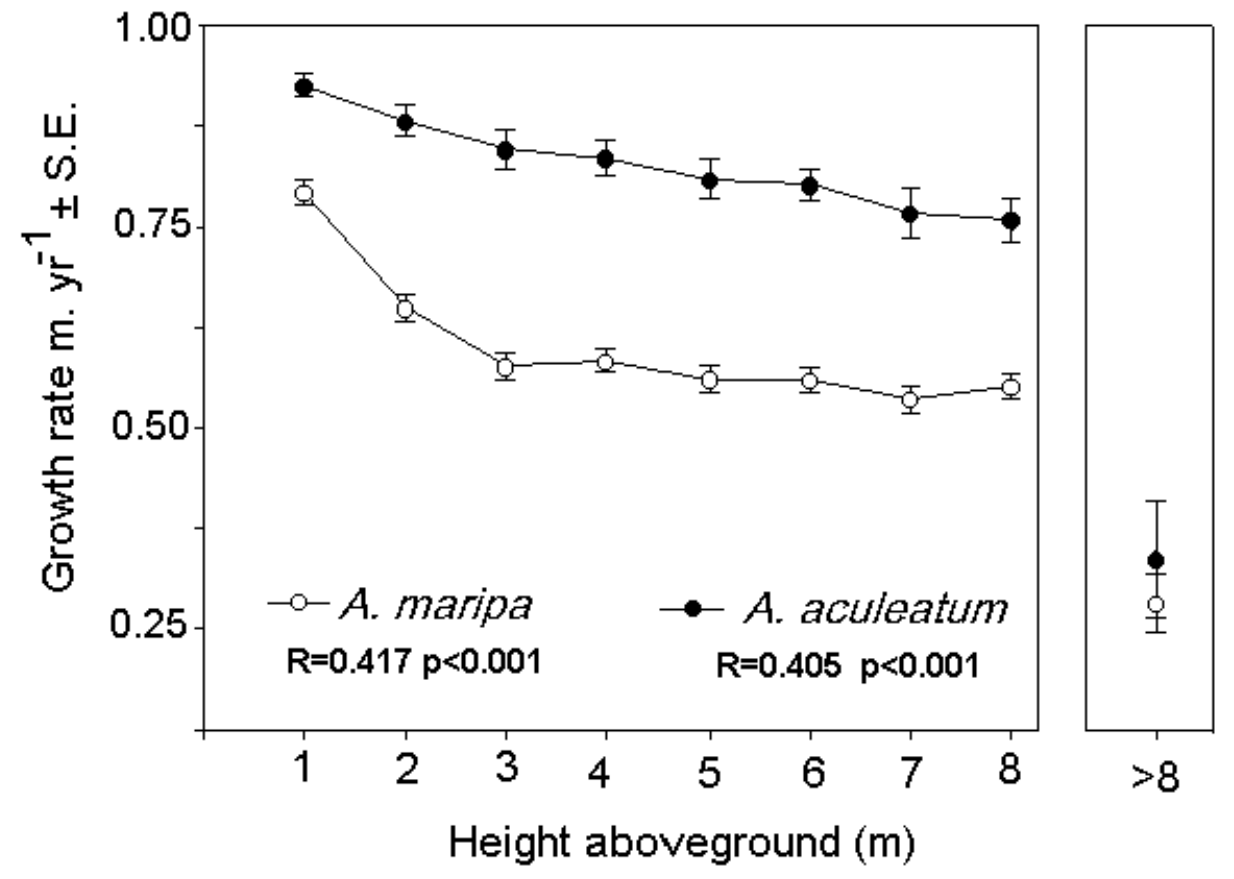

FIGURE 4. The relationship between growth rate and height of A. maripa and A. aculeatum at Pinkaití Site, Brazil. based on leaf scar per ( $m$ ) and average production rates. 


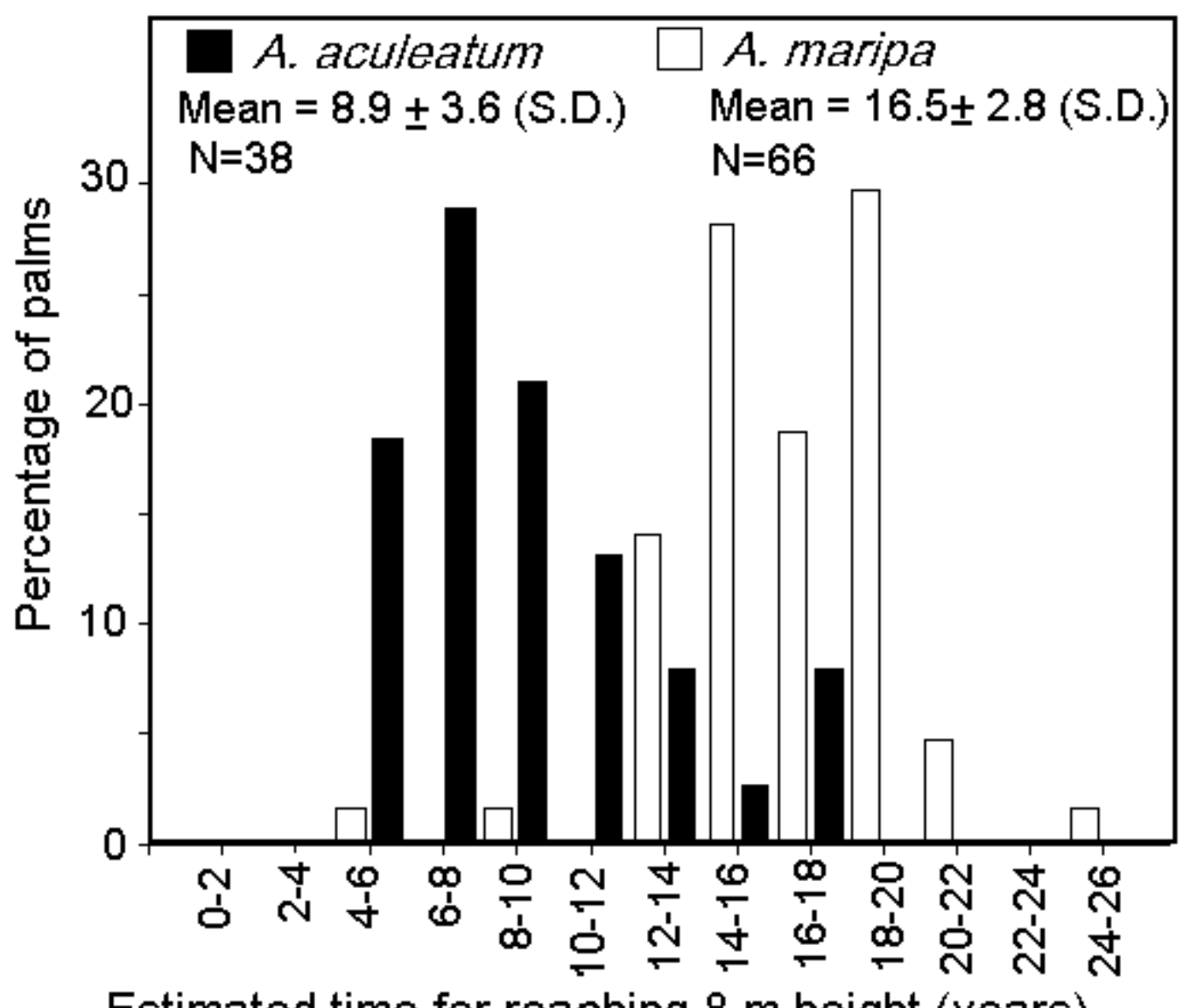

Estimated time for reaching $8 \mathrm{~m}$ height (years)

FIGURE 5. Frequency distribution of estimated time of stem development since emergence up $8 m$ height for A. maripa and A. aculeatum at the Pinkaití site, Brazil. 
the top. Differences were found between the density patterns found across the stem of A. maripa and A. aculeatum. Stem density of $A$. maripa was substantially more homogeneous both from the centre to its external parts, and from the base of the stem towards the crown.

The results show that the stem growth rates of both A. maripa and A. aculeatum are higher at an earlier period after emergence from the ground level, compared to the late development period. On the other hand, the reproductive activity of palms of both species was lower at an earlier period after emergence from the ground, and increased at a later development period. Stem growth rate of $A$. maripa was high at the first metre of aboveground development, declining sharply from 1 to $2 \mathrm{~m}$ and then stabilising before substantially decreasing in taller palms at heights greater than $8 \mathrm{~m}$. The stem growth rate of $A$. aculeatum, in turn, was higher when compared to that of A. maripa and had a smoother decline during the early development period, becoming similarly low at late maturity.

That stem density increases towards the stem periphery and the base has been reported to occur, to varying extents, among other arborescent palms (e.g. Cocos nucifera: Richolson \& Swarup 1977, Sudo 1980, Killmann 1983, Iriartea gigantea, Socratea durissima: Rich 1987a). The finding that A. maripa stem density is much more homogeneous than that of A. aculeatum is also consistent with observations that palm tree species can range widely in the extent to which density varies across the stem (Tomlinson 1961, 1979, 1990, Zimmermann 1973, Rich 1987b, 1987a).

Within energetic constraints, stem density should be inversely related to stem growth, a relationship that holds among tropical forest trees (Richards 1952, Whitmore 1975, 1984, 1989, Fearnside 1997). The smaller differences in early and late growth rates of $A$. maripa stem, when compared to A. aculeatum, is likely to be directly related to the smaller differences in density patterns found across the stem of this species. A reduction in growth rate in mature to senescent palms has also been observed to be a common feature in palm tree species. Its adaptive value is likely to be related to both decreasing net benefits from greater luminosity and increasing probability of stem breakage in taller plants. Although the energetic costs associated with the reproductive activity of mature individuals might be a confounding variable (Corner 1964, Tomlinson 1990, Alvarez-buylla \& Garay 1994, Alvarez-Buylla et al. 1996).

Sample size limitation, at the present work, hindered refinements on the relationships between environmental heterogeneity created by the vegetation and the density, structure and growth of the stems of each specie. However, the information available is enough to draw a broad picture of large arborescent palm developmental contrasts, and the main differences between A. maripa and A. aculeatum. At the Pinkaití site, palm trees, as a group, are more abundant in more open forests. The same pattern holds at the scale of the entire Amazon basin, as large arborescent palms are more frequently found in structurally open, seasonally dry forests, that predominate along the Southern and Eastern fringes of the region (Kahn \& Granville 1992). However, forest structure does not seem to affect the abundance of $A$. maripa and $A$. aculeatum in the same way, since the abundance ratio of the former to the latter is increases with structurally more open forests (Salm 2002).

Large forest patches dominated by palm trees do not occur naturally in terra firme forest at the Pinkaití site. Indeed, palm-dominated forest patches in well-drained areas of Amazonia of a few to several hectares, seem to be related to past human disturbance (Ballée 1989, Ballée and Cambell 1990, Anderson et al. 1991, Kahn and Granville 1992). Numerous monodominant forest enclaves of 2-3 ha of Attalea phalerata (babassu) in the Brazilian State of Maranhão are often associated with old human settlement sites (Ballée 1984). In fragments of the Atlantic forest, in Southeastern Brazil, the presence of large disturbed sectors promotes the formation of large, continuous stands of the acaulescent palm Attalea humilis (Souza \& Martins 2002).

The higher overall stem density of the shorter $A$. maripa palms, in comparison to A. aculeatum, give this species a wider structural safety margin during early stem growth. Such safety margin should make this species less likely to be fatally damaged by physical disturbance at an early stage. This is especially advantageous under the high disturbance regime that is typical of structurally more open forests like many parts of the Pinkaití forest. Despite having larger stem diameter, A. maripa seems to have a lower capacity to increase density later on during the stem development process, which is likely to make taller palms of this species more vulnerable to stem breakage. This could confer a further disadvantage for A. maripa, in relation to $A$. aculeatum, in more built-up, taller forests. Such patterns are consistent with the distributional contrasts of A. maripa and $A$. aculeatum across structurally distinct forests and could provide a mechanism for avoiding the competitive exclusion of either species across most of the Amazon.

\section{Bibliographic References}

1.ALVAREZ BUYLLA, E.R. \& GARAY, A.A. 1994. Population Genetic-Structure of Cecropia obtusifolia, a Tropical Pioneer Tree Species. Evolution 48: 437-453.

2.ALVAREZ BUYLLA, E.R., GARCIA BARRIOS, R., LARAMORENO, C. \& MARTINEZ RAMOS, M. 1996. Demographic and Genetic Models in Conservation Biology: Applications and Perspectives for Tropical Rain Forest Tree Species. Annu. Rev. Ecol. Syst. 27: 387-421.

3.ANDERSON, A.B., MAY P. H., \& BALICK M. 1991. The Subsidy from Nature. New York, Columbia University Press. 
4.BAIDER, C. 2000. Demografia e ecologia de dispersão de frutos de Bertholletia excelsa Humb. 7 Bonpl. (Lecythidaceae) em castanhais silvestres da Amazônia Oriental. Tese de Doutorado. Departamento de Ecologia. São Paulo, Universidade de São Paulo, Brazil.

5.BALLÉE, W. 1989. The Culture of Amazonian Forests. Adv. Econ. Bot. 7: 1-21.

6.BALLÉE, W., CAMBELL D. G. 1990. Evidence for the successional status of liana forest (Xingú river basin, Amazonian Brazil). Biotropica 22: 36-47.

7.BODMER, R.E. 1991. Strategies of Seed Dispersal and Seed Predation in Amazonian Ungulates. Biotropica 23: 255261.

8.CAMPBELL, D. G., DALY, D. C.; PRANCE, G. T.; MACIEL, U. N. 1986. Quantitative ecological inventory of terra firme and Várzea tropical forest on the Rio Xingú, Brazilian Amazon. Brittonia 38: 369-393.

9.CONNELL, J.H. 1978. Diversity in Tropical Rain Forests and Coral Reefs. Science 199: 1302-1310.

10.CORNER, E.J.H. 1964. The Natural History of Palms. London, Weidenfeld \& Nicolson.

11.DE GRANVILLE, J. 1992. Life Forms and Growth Strategies of Guianan Palms as Related to their Ecology. Bull. I. Fr. Étud. And. 21: 533-548.

12.FEARNSIDE, P.M. 1997. Wood Density for Estimating Forest Biomass in Brazilian Amazonia. For. Ecol. Manage. 90: 59-87.

13.FRAGOSO, J.M.V. 1994. Large Mammals and the Community Dynamics of an Amazonian Rainforest. Florida, $\mathrm{PhD}$ thesis, University of Florida.

14.FRAGOSO, J.M.V. 1997. Tapir-Generated Seed Shadows: Scale-Dependent Patchiness in the Amazon Rain Forest. J. Ecol. 85: 519-529.

15.FRAGOSO, J.M.V. 1998). Home Range and Movement Patterns of White-Lipped Peccary (Tayassu pecari) Herds in the Northern Brazilian Amazon. Biotropica 30: 458-469.

16.FRAGOSO, J.M.V. 1999. Perception of Scale and Resource Partitioning by Peccaries: Behavioral Causes and Ecological Implications. J. Mammal. 80: 993-1003.

17.GIVNISH, T.J. 1979. On the Adaptive Significance of Leaf Form. In Topics in plant population biology (O. T. Solbrig, S. Jain, G. B. Johnson \& P. H. Raven eds.). Columbia University Press, New York, p. 375-407.

18.GIVNISH, T.J. 1988. Adaptation to Sun and Shade: a Whole-Plant Perspective. Aust. J. Plant Physiol. 15: 6392.

19.HENDERSON, A., GALEANO, G. \& BERNAL, R. 1995. Field Guide to the Palms of the Americas. Princeton University Press, Princeton.
20.KAHN, F. 1986. Life Forms of Amazonian Palms in Relation to Forest Structure and Dynamics. Biotropica 18: 214-218.

21.KAHN, F. 1987. The Distribution of Palms as a Function of Local Topography in Amazonian Terra Firme forests. Experientia 43: 251-259.

22.KAHN, F. \& CASTRO, A. 1985. The Palm Community in a Forest of Central Amazonia, Brazil. Biotropica 20: 266269.

23.KAHN, F. \& GRANVILLE, J. 1992. Palms in forest Ecosystems of Amazonia. Springer Verlag, Heidelberg.

24.KILLMANN, W. 1983. Some Physical Properties of the Coconut Palm Stem. Wood Sci. Tech. 17: 167-185.

25.PIÑERO, D., MARTINEZRAMOS, M. \& SARUKHAN, J. 1984. A Population-Model of Astrocaryum-Mexicanum and a Sensitivity Analysis of Its Finite Rate of Increase. J. Ecol. 72: 977-991.

26.PIRES, J. M., PRANCE, G. T. 1985. Vegetation types of the Brazilian Amazonia. Amazonia. Prance, G. T. and Lovejoy, T. E. Oxford, Pergamon Press.

27.RADAM 1974. Projeto RadamBrasil. Folha SB22 Araguaia e parte da folha SC 22 Tocantins. Rio de Janeiro, Instituto Brasileiro de Geografia e Estatística.

28.RICH, P.M. 1986. Mechanical Architecture of Arborescent Rain Forest Palms. Principes 30: 117-131.

29.RICH, P.M. 1987a. Developmental Anatomy of the Stem of Welfia georgii, Iriartea gigantea, and Other Arborescent Palms - Implications for Mechanical Support. Am. J. Bot. 74: 792-802.

30.RICH, P.M. 1987b. Mechanical Structure of the Stem of Arborescent Palms. Bot. Gaz. 148: 42-50.

31.RICHARDS, P.W. 1952. The tropical Rain Forest. Cambridge University Press, Cambridge.

32.RICHARDS, P. \& G.B. WILLIAMSON 1975. Treefalls and Patterns of Understorey Species in a Wet Lowland Forest. Ecology 56: 1226-1129.

33.RICHOLSON, J.M. \& R. SWARUP 1977. The Anatomy, Morphology, and Physical Properties of the Mature Stem of Coconut Palm. In Proceedings of the Coconut Utilization Seminar held in Tonga 1976 (A. K. Familton, A. J. McQuire, J. A. Kininmonth \& A. M. L. Bowles, eds.) Wellington, N.Z, Ministry of Foreign Affairs, Tonga.

34.SALM, R. 2002. The ecology of large arborescent palms, Attalea maripa and Astrocaryum aculeatum in a seasonally-dry Amazonian forest. M.Sc. thesis. School of Environmental Sciences, University of East Anglia, Norwich.

35.SARUKHAN, J. 1978. Studies on the Demography of Tropical Trees. In Tropical trees as living systems (P.B. Tomlinson \& H. Zimmerman eds.). Cambridge University Press, Cambridge. 
36.SAVAGE, A. J. \& ASHTON, P. S. 1983. The Population Structure of the Double Coconut and some other Seychelles Palms. Biotropica 15:15-25.

37.SOUZA, A.F. \& MARTINS, F.R. 2002. Spatial distribution of na undergrowth palm in fragments of the Brazilian Atlantic Forest. Plant Ecol. 164:141-155.

38.SOUZA, A.F. MARTINS, F.R. \& BERNACCI, L.C. 2003. Clonal growth and repreoductive strategies of the understory tropical palm Geonoma brevispatha: an ontogenetic approach. Can. J. Bot. 81:101-112.

39.SPRUCE, R. 1871. Palmae Amazonicae. Bot. J. Linn. Sc. 11:65-183.

40.SUDO, S. 1980. Some Anatomical Properties and Density of the Stem of Coconut Cocos nucifera with Consideration of Pulp Quality. IAWA Bull. 1: 161-171.

41.SVENNING, J.-C. 1999. Recruitment of Tall Arborescent Palms in the Yasuni National Park, Amazonian Ecuador: are Large Treefall Gaps Important? J. Trop. Ecol. 15: 355366.

42.SVENNING, J.-C. 2000. Growth Strategies of Clonal Palms (Arecaceae) in a Neotropical Rain Forest, Yasuní, Equador. Aust. J. Bot. 48: 167-178.

43.SVENNING, J.-C. 2001. On the role of microenvironmental heterogeneity in the ecology and diversification of neotropical rain-forest palms (Arecaceae). Bot. Rev. 67:153.

44.TOMLINSON, P.B. 1961. Anatomy of Monocotyledons. II. Palmae. Claredon Press, Oxford.

45.TOMLINSON, P.B. 1979. Systematic and Ecology of the Palmae. Annu. Rev. Ecol. Syst.10: 85-107.

46.TOMLINSON, P.B. 1990. The Structural Biology of Palms. Clarendon Press, Oxford.

47.TOMLINSON, P.B. \& ZIMMERMAN, M.H. 1967. The "Wood" of Monocotyledons. Bull. Int. Assoc. Wood Anat. 1967/2: 4-24.

48.UHL, C. \& DRANSFIELD, J. 1987. Genera Palmarum. Allen Press, Kansas.

49.WATERHOUSE, F.L.S. \& QUINN, C.J. 1978. Growth Patterns in the Stem of the Palm Archontophoenix cunninghamiana. Bot. J. Linn. Soc. 77: 73-93.

50.WHITMORE, T.C. 1975. Tropical rain forests of the Far East. Clarendon Press, Oxford.

51.WHITMORE, T.C. 1984. Gap Size and Species Richness in Tropical Rain Forest Trees. Ecology 70: 536-538.

52.WHITMORE, T.C. 1989. Canopy gaps and the Two Major Groups of Forest Trees. Ecology 70: 536-538.

53.WILLIAMSON, G.B. 1984. Gradients in Species Richness and Wood Specific Gravity of Trees. Bull. Torrey Bot. Club 111: 51-55.
54.ZIMMERMANN, M.H. 1973. The Monocotyledons: their Evolution and Comparative Biology. IV. Transport Problems in Arborescent Monocotyledons. Q. Rev. Biol. 48: 314-321.

Title: Stem density, growth and the distribution of palm trees

Author: Rodolfo Salm

Biota Neotropica, Vol.4 ( number 1): 2004

http://www.biotaneotropica.org.br/v4n 1/pt/ abstract?article+BN00104012004

Date Received: 06/27/2003

Revised: 09/25/2003

Accepted: 01/05/2004

ISSN 1676-0611

http://www.biotaneotropica.org.br 